O'Dea, J. F. \& Dineen, J. K. (1957). J. gen. Microbiol. 17, 19-24

\title{
Fluorescent Antibody Studies with Herpes Simplex Virus in Unfixed Preparations of Trypsinized Tissue Cultures
}

\author{
BY J. F. O'DEA AND J. K. DINEEN
}

The Walter and Eliza Hall Institute of Medical Research, Melbourne, Australia

SUMMARY: The classical strain of herpes simplex virus (Burnet \& Lush, 1939) and a recently isolated strain (Melbourne 1/56) were propagated in tissue culture of human amnion and infant-mouse kidney 'epithelial' cells. Following the inoculation of $10^{8.25} \mathrm{TCCD}_{50}$ (tissue culture cytopathogenic dose) of the Melbourne 1/56 herpes simplex virus into amnion cell culture, the titre of virus dropped to $10^{0.50} \mathrm{TCCD}_{50}$ at $12 \mathrm{hr}$. and the maximum level of virus $\left(10^{8.50} \mathrm{TCCD}_{50}\right)$ was detected at $48 \mathrm{hr}$. after inoculation. The earliest morphological changes were observed in the tube-cultures c. $18 \mathrm{hr}$. after inoculation of the virus and eosinophilic intranuclear inclusion bodies were observed in the amnion cells $c$. 24 hr. after virus injection. Cell degeneration was prominent at $36 \mathrm{hr}$. when most cells were highly refractile and rounded. Cell suspensions, harvested from infected and uninfected cultures of amnion and mousekidney epithelium, were treated with immune herpes serum followed by fluorescent rabbit anti-human $\gamma$-globulin, and specific peripheral fluorescence was observed in the unfixed preparations of the infected tissue cultures. The limited surface staining was ascribed to the impermeability of the unfixed cytoplasmic membranes to globulins.

Weller \& Coons (1954) by using the 'double-layer technique' in fluorescent antibody studies, showed that varicella and herpes zoster viruses propagated in tissue culture of human embryonic skin, muscle and foreskin. These workers used, as a control of the new technique, tissue culture preparations infected with herpes simplex virus. It is the purpose of the present communication to record work on the specific fluorescent staining of herpes simplex virus in tissue cultures. During this work the non-specific fluorescence which we have observed in acetone-fixed preparations was decreased by use of unfixed preparations.

\section{METHODS}

Human amnion cell cultures. Single cells and small cell-aggregates were released from the amnions by trypsinization. The cell suspensions were washed once with Earle's saline (Earle, 1943) and resuspended at a concentration of $\mathbf{1 5 0 , 0 0 0}$, single cells and cell-aggregates $/ \mathrm{ml}$. in a nutrient medium of $30 \%(\mathrm{v} / \mathrm{v})$ heat-inactivated horse serum, $5 \%(\mathrm{w} / \mathrm{v})$ lactalbumin hydrolysate and $65 \%$ (v/v) Earle's saline. Penicillin (100 units $/ \mathrm{ml}$.) and streptomycin (100 $\mu \mathrm{g} . / \mathrm{ml}$.) were added to the complete medium. The $\mathrm{pH}$ value of the final cells suspensions was adjusted to the acid side of neutrality $(c . \mathrm{pH} 6 \cdot 8)$ with carbon dioxide and samples $(1 \mathrm{ml}$.) were dispensed into roller tubes. After incubation of the cultures at $37^{\circ}$ for 3 days in stationary racks, the medium was changed and the cultures set rotating at $40 \mathrm{rev} . / \mathrm{hr}$. When luxuriant proliferation of the cells had occurred (about the 7th or 8th day) the medium was again replaced and the cultures were then ready for virus inoculation. 
Infant-mouse kidney-cell cultures. The cultures of infant-mouse kidney epithelium were similarly prepared, but more rapid proliferation occurred. The cultures were generally ready for virus inoculation by the 5 th day after trypsinization.

Harvesting of tissue cultures. Infected and uninfected sheets of cells were released from the surface of the tubes by adding $1 \mathrm{ml.} 0.25 \%(\mathrm{w} / \mathrm{v})$ trypsin at $37^{\circ}$. Infected cultures were harvested on the first and second days following virus inoculation. The cell suspensions from each tube were washed twice and re-suspended in $\mathbf{0 \cdot 2} \mathrm{ml}$. phosphate buffered saline ( $\mathrm{pH} \mathrm{7 \cdot 0)}$ and the cell concentrates so obtained were then ready for treatment with fluorescent antibody.

Herpes simplex virus. The classical HFE strain (Burnet \& Lush, 1939) and a strain (Melbourne $1 / 56$ ) isolated from herpetic vesicle fluid in tissue culture of human amnion cells, were used throughout the present studies. The Melbourne 1/56 and the HFE viruses were maintained through six and two serial amnion cell passages, respectively, before use.

Nerwcastle disease virus. The strain of NDV isolated by Albiston \& Gorrie (1942) was used in the control studies.

Virus titrations. Titration of the Melbourne 1/56 herpes simplex virus was carried out in amnion cell tissue culture at tenfold dilutions with six tubes/ dilution, and examined under low-power light microscopy for cytopathogenic effects on the 5th and 7 th day after inoculation. Virus titres were estimated by the method of Reed \& Muench (1938).

Virus titres were estimated on the supernatant fluid of pools of six amnion cell cultures at intervals following inoculation with 6th-passage material of the Melbourne 1/56 herpes simplex virus. The inoculum $(0.05 \mathrm{ml}$.) contained $10^{3.25}$ tissue culture cytopathogenic doses ${ }_{50}\left(\mathrm{TCCD}_{50}\right)$ of virus and specimens were harvested at 12, 24, and $36 \mathrm{hr}$. and 2,3 and 5 days.

Preparation of rabbit anti-human $\gamma$-globulin. Electrophoretically homogeneous $\gamma$-globulin (Commonwealth Serum Laboratories; $2 \mathrm{ml}$.; $320 \mathrm{mg}$. protein) was intimately dispersed with sterile 'Arlacel A' $(0.25 \mathrm{ml}$.) by using a $5 \mathrm{ml}$. syringe and an 18-gauge needle. Sterile 'Bayol F' (1.5 ml.) was slowly incorporated into the mixture and the fine opalescent emulsion so obtained $(3.75 \mathrm{ml}$.) was injected intramuscularly into the thighs of an adult male rabbit. The rabbit was bled from the marginal ear vein 3 weeks after injection and the serum had a titre of $1 / 25,000$ against a one in four dilution of the human $\gamma$-globulin in physiological saline when tested by ring precipitation.

The rabbit antiserum yielded a pseudoglobulin fraction when treated with ammonium sulphate (Coons \& Kaplan, 1950) or with methanol at $0^{\circ}$ (Pillemer \& Hutchinson, 1945). Subsequent coupling of this pseudoglobulin fraction with fluorescein isocyanate was essentially as described by Coons \& Kaplan, 1950; comparable results were obtained when either aminofluorescein I, aminofluorescein II, or mixtures of these isomers were employed as starting materials. After dialysis at $4^{\circ}$, the coupled antibody (with merthiolate added to $1 / 10,000$ ) was stored at $-15^{\circ}$; immediately before use small portions were absorbed twice with acetone-extracted mouse liver (Coons \& Kaplan, 1950). 
Human sera. The neutralizing activity of the human sera used in this work was assessed by the inhibition or otherwise of the development of pocks on the chorioallantoic membrane of eggs following the inoculation of 100 egginfective doses of herpes simplex virus. Several immune and non-immune sera were thus obtained. All human sera were kept at $-20^{\circ}$ without preservative, and were inactivated at $56^{\circ}$ for $30 \mathrm{~min}$. before use.

Staining technique. Preliminary investigations indicated that fixation by acetone or by $95 \%(\mathrm{v} / \mathrm{v})$ ethanol in water enhanced the degree of non-specific staining; unfixed cell preparations were therefore used throughout this work.

Infected and uninfected trypsinized 'cell concentrates' (c. $0.2 \mathrm{ml}$; see Harvesting of tissue cultures) were treated separately in small centrifuge tubes with 1.0-1.5 ml. of a $1 / 10$ dilution of herpes-immune human serum in phosphate buffered saline ( $\mathrm{pH} 7 \cdot 0$ ). After $30 \mathrm{~min}$. with occasional shaking, the cell suspensions were lightly centrifuged at $2500 \mathrm{rev}$./min. for $3 \mathrm{~min}$. and the supernatant fluids carefully removed. The cell deposits were washed twice within $15 \mathrm{~min}$. with phosphate buffered saline $(\mathrm{pH} 7 \cdot 0)$ and treated with $0.3 \mathrm{ml}$. of absorbed fluorescein-conjugated rabbit anti-human $\gamma$-globulin for 30 min. with occasional shaking. The cell preparations were then centrifuged and washed twice with phosphate buffered saline (pH 7.0), and finally suspended in $\mathbf{0 . 2} \mathrm{ml}$. of the same phosphate buffered saline. A drop of the stained cell suspensions was placed on a slide under a coverslip and examined in the fluorescence microscope.

Optical and photographic equipment. The simplified fluorescence microscope described by Matthaei (1950) and Hicks \& Matthaei (1955) was used throughout this work, thereby eliminating the need for mercury vapour or arc lamps or for an expensive quartz condenser. The microscope was fitted with an Abbe condenser, a fixed oil condenser of N.A. 1.4, and a decentrable iris diaphragm. A Kodak Wratten G. 15 filter was used in the ocular. Visible blue light for the excitation of fluorescence was obtained by an ammoniacal copper sulphate filter inserted between the light source (a 12 V. $100 \mathrm{~W}$. projection lamp) and the condenser. In using this microscope, it was found that by partly closing the diaphragm and moving it horizontally off centre, a pseudo darkground effect was produced. This effect allowed identical fields to be photographed under darkground or fluorescence conditions. Photographs were taken with an Exacta Varex camera using Kodak Tri X film. Exposure times were $5 \mathrm{~min}$. for fluorescence photographs and $\frac{1}{5}$ to $\frac{1}{25} \mathrm{sec}$. for darkground photographs.

Controls. The following control systems were investigated, using infantmouse kidney cells and human amnion cells in tissue culture:

(a) Uninoculated tissue cells treated with: (i) fluorescent rabbit antihuman $\gamma$-globulin; (ii) herpes non-immune human serum followed by fluorescent rabbit anti-human $\gamma$-globulin; (iii) herpes immune human serum followed by fluorescent rabbit anti-human $\gamma$-globulin.

(b) Tissue cells inoculated with herpes simplex virus (one or two days after inoculation and showing obvious cell infection and rounding off) treated with: (i) herpes non-immune human serum followed by fluorescent rabbit anti- 
human $\gamma$-globulin; (ii) herpes immune serum followed by normal rabbit serum conjugated with fluorescein isocyanate.

(c) Tissue cells inoculated with Newcastle disease virus (2 days after inoculation and showing cell necrosis) treated with: herpes immune serum followed by fluorescent rabbit anti-human $\gamma$-globulin.

\section{RESULTS}

Virus growth. Following the inoculation of $10^{3.25} \mathrm{TCCD}_{50}$ of the Melbourne 1/56 herpes simplex virus into amnion cell culture, the titre of virus dropped to $10^{0.50} \mathrm{TCCD}_{50}$ at $12 \mathrm{hr}$. and the maximum level of virus $\left(10^{3.50} \mathrm{TCCD}_{50}\right)$ was detected at $48 \mathrm{hr}$. after inoculation.

Light microscopy. The earliest morphological changes were observed in the tube-cultures $c$. $18 \mathrm{hr}$. after inoculation of the virus, when the cytoplasm of the cells became more refractile and granular. Characteristic eosinophilic intranuclear inclusion bodies were observed in the amnion cells $c .24 \mathrm{hr}$. after virus injection and cell degeneration was prominent at $36 \mathrm{hr}$. when most cells were highly refractile, rounded and readily differentiated from the polygonalshaped uninfected 'epithelial' cells. Occasionally multinucleated syncytiallike masses were observed in infected cultures when degeneration was advanced on the second and third day after virus inoculation. Similar morphological changes were observed in amnion cells infected with the classical HFE strain of herpes simplex virus.

Fluorescence microscopy. No specific yellow-green fluorescence was observed in any of the controls. Apparently the ocular filter (Wratten G15) transmitted some blue light as both infected and uninfected cells were generally visible in vague outline in the fluorescence microscope as a faint blue-grey luminescence rather than a fluorescence. This effect was more obvious in old tissue culture preparations when presumably the proportion of dead cells was high. When infected cells were treated with immune herpes serum, followed by fluorescent rabbit anti-human $\gamma$-globulin, the resulting fluorescence was of the kind shown in Pl. 1 and 2, figs. 1-4; darkground photographs of the same cells are included for comparison (Pls. 1 and 2, figs $1 b-4 b$ ). Heavily infected cells were readily distinguished from others by the bright peripheral fluorescence which was characteristically yellow-green. Definite intracellular fluorescence was occasionally observed but it was not possible to interpret whether such fluorescence was nuclear or cytoplasmic. With the mouse kidney system the peripheral fluorescence was again marked (Pl. 2, fig. 4), and the over-all cellular fluorescence was more pronounced.

Using the single criterion of peripheral fluorescence in groups of infected cells, eight randomly selected human sera were assayed by the fluorescence technique. Five of these sera gave regular bright fluorescence when applied to infected cells, while the remaining three gave no fluorescence under the same conditions. This result correlated with the neutralization tests in which fluorescence-positive sera were found to inhibit the growth of herpes simplex in eggs, while the fluorescence-negative sera gave no inhibition. 


\section{DISCUSSION}

The correlation of the results obtained with fluorescence microscopy and those of the neutralization tests shows that the 'double-layer technique' gives unequivocal results in the herpes simplex tissue culture systems described above. Providing that adequate controls are included, the use of the technique of using fluorescent rabbit anti-human $\gamma$-globulin eliminates the need for a conjugated specific fluorescent antiserum for each infecting agent. In this work we have included the controls used by other workers as well as a separate control with Newcastle disease virus. No fluorescence was detected in cell preparations stained with the double-layer technique with herpes immune serum, when necrosis was induced by Newcastle disease virus. Thus cell damage by a virus agent serologically unrelated to the immune serum did not, per se, give rise to uptake of specific fluorescent material.

In most of our positive preparations, the fluorescence observed was of the peripheral type; this we consider largely due to the use of unfixed preparations. The peripheral or surface staining was attributed to the impermeability of the cytoplasmic membrane to immune- and fluorescein-conjugated globulins. Cytoplasmic or nuclear staining was not convincingly observed, despite the use of $24 \mathrm{hr}$. infected cultures in which intranuclear inclusions were demonstrated by ordinary light microscopy.

Both fluorescing and non-fluorescing cells were observed in the virusinoculated tissue cultures. Thus, while some cells were obviously infected and absorbed fluorescent antibody through the specific $\gamma$-globulin bridge, virus-infection of the unstained cells cannot be confidently postulated.

We are indebted to Dr E. L. French and Dr S. G. Anderson for much advice and assistance, and to Sir Macfarlane Burnet for his interest and guidance throughout the course of this work. One of us (J.F.O'D.) carried out this work while on loan from the Commonwealth Department of Supply; J.K. D. was in receipt of a grant from The National Health and Medical Research Council, Canberra, Australian Capital Territory.

\section{REFERENCES}

Albiston, H. F. \& Gorrie, C. J. R. (1942). Newcastle disease in Victoria. Aust. vet. $J .18,75$.

Burnet, F. M. \& LUSH, D. (1939). The inactivation of herpes virus by immune sera: experiments using the chorio-allantoic membrane technique. J. Path. Bact. 48, 275.

Coons, A. H. \& Kaplan, M. H. (1950). Localization of antigen in tissue cells. II. Improvements in a method for the detection of antigen by means of fluorescent antibody. J. exp. Med. 91, 1.

Earle, W. R. (1943). Production of malignancy in vitro. IV. The mouse fibroblast cultures and changes seen in the living cells. J. nat. Cancer Inst. 4, 165.

Hicks, J. D. \& MatThaei, E. (1955). Fluorescence in histology. J. Path. Bact. 70, 1.

MatrhaeI, E. (1950). Simplified fluorescence microscopy of tubercle bacilli. J. gen. Microbiol. 4, 393.

Pillemer, L. \& Hutchinson, M. C. (1945). Determination of albumin and globulin contents of human serum by methanol precipitation. J. biol. Chem. 158, 299. 
Reed, L. J. \& Muench, H. (1938). Simple method of estimating fifty per cent endpoints. Amer. J. Hyg. 27, 493.

Weller, T. H. \& Coons, A. H. (1954). Fluorescent antibody studies with agents of varicella and herpes zoster propagated in tissue culture. Proc. Soc. exp. Biol., N.Y. 86, 789.

\section{EXPLANATION OF PLATES}

\section{Plate 1}

Fig. 1a. Human amnion cells infected with herpes simplex (Melb. 1/56) and stained with fluorescent antibody $24 \mathrm{hr}$. after addition of the virus. (Magnification, $\times 600$.)

Fig. 1b. Darkground micrograph of same field shown in Fig. $1 a$.

Fig. 2a. Human amnion cells infected with herpes simplex (HFE) and stained with fluorescent antibody $48 \mathrm{hr}$. after addition of the virus. (Magnification, $\times 600$.)

Fig. 2b. Darkground micrograph of same field shown in Fig. $2 a$.

\section{Plate 2}

Fig. 3a. Human amnion cells infected with herpes simplex (Melb. 1/56) and stained with fluorescent antibody $48 \mathrm{hr}$. after addition of the virus. (Magnification, $\times 520$.)

Fig. $3 b$. Darkground micrograph of the same field shown in Fig. $3 a$.

Fig. 4a. Infant-mouse kidney cells infected with herpes simplex (HFE) and stained with fluorescent antibody $24 \mathrm{hr}$. after addition of the virus. (Magnification, $\times 480$.)

Fig. $4 b$. Darkground micrograph of the same field shown in Fig. $4 a$.

(Received 5 November 1956) 
Journal of General Microbiology, Vol. 17, No. 1
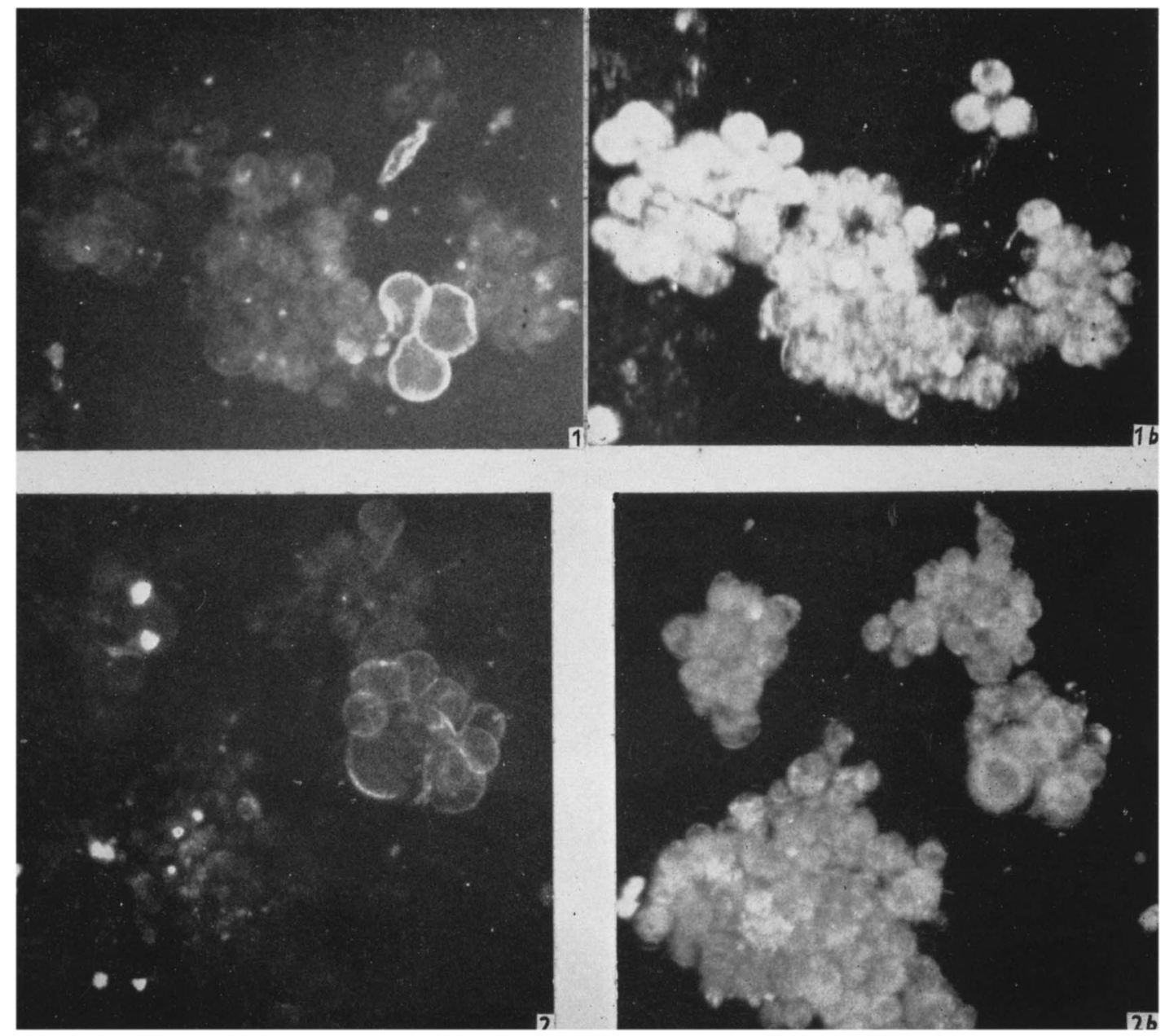

J. F. O'Dea and J. K. Dineen-Fluorlescent antibody studies. Plate 1

(Facing p. 24) 
Journal of General Microbiology, Vol. 17, No. 1
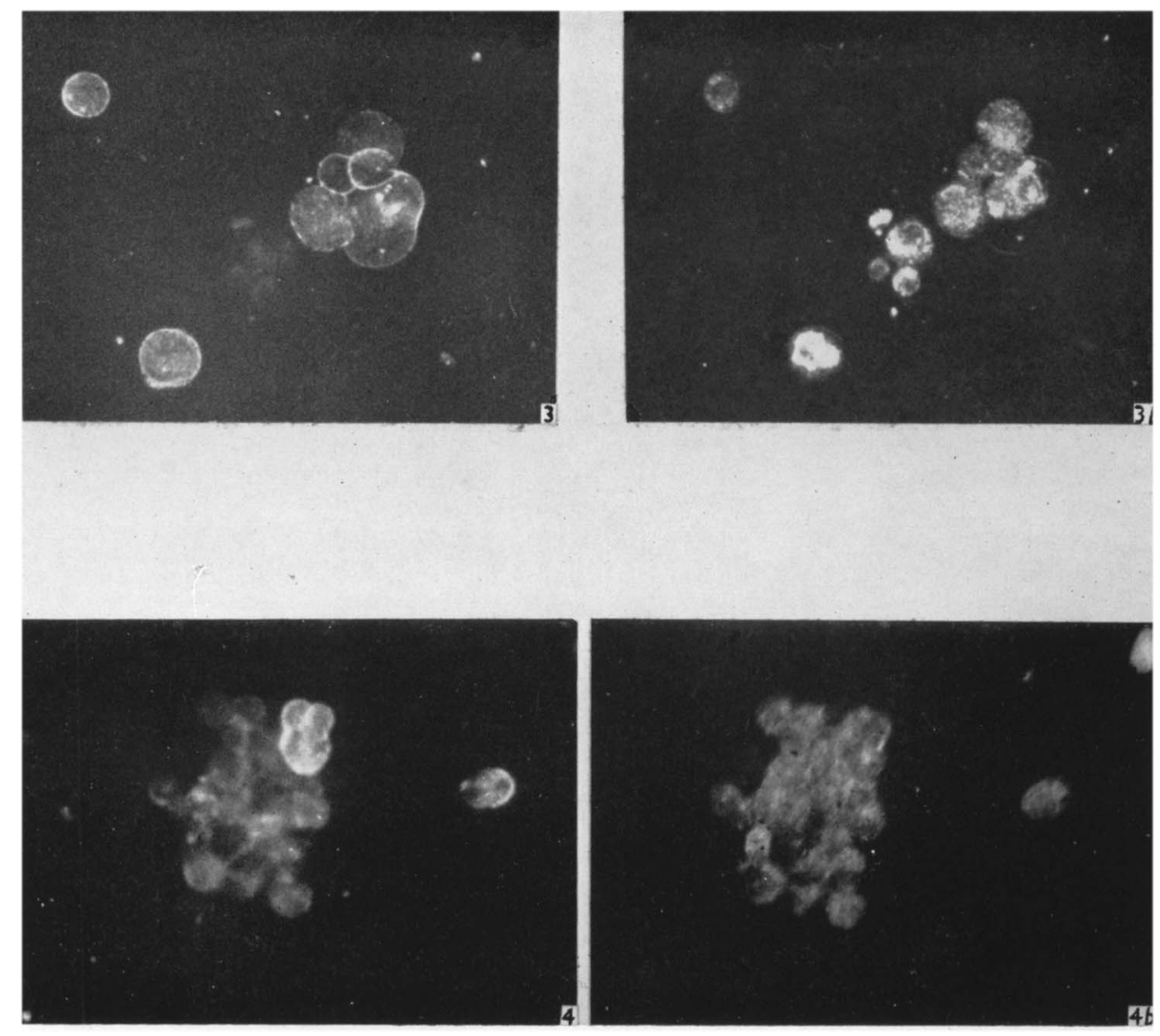

J. F. O'Dea and J. K. Dineen-Fluorescent antibody studies. Plate 2 